\title{
CONCENTRATION OF HEAVY METALS IN EDIBLE PLANTS POTATOES: THE HEALTH EFFECTS IN THE HUMAN ORGANISM
}

\author{
Ibrahim Hoxha ${ }^{1}$, Nexhdet Shala ${ }^{1, *}$ and Gafur Q Xhabiri ${ }^{2}$ \\ ${ }^{1}$ Faculty of Agribusiness, University of "Haxhi Zeka", Peja-30000 Kosovo \\ ${ }^{1}$ Faculty of Agribusiness, University of "Haxhi Zeka", Peja-30000 Kosovo \\ ${ }^{2}$ Faculty of Food Technology and Nutrition, University of Tetova, R. Macedonia \\ *E-mail: nexhdet.shala@unhz.eu
}

\begin{abstract}
With the emergence of Homo sapiens, the pollution of the environment at that time was of marginal scale, however, the development of world industry and mining activities are also impacting the Republic of Kosovo, given that the latter is starting to feel the environment pollution. The environment impact emerged as a result of poor management of urban waste and the circulation of over 500000 cars in the streets of Kosovo. Over 85\% of cars do not have catalytic converter; they are produced before 1980, whereas the other $15 \%$ are produced after 1980. The worst polluted municipalities in Kosovo are Mitrovica and Obiliq as a result of industrial activities such are: Trepca mine and the power plants of Kosovo with the heavy emissions in nature without prior treatment such are: $\mathrm{Pb}, \mathrm{Zn}, \mathrm{Ni}, \mathrm{Cu}$, $\mathrm{Cd}$. The uncontrolled, heavy utilization of pesticides and herbicides has a great contaminating effect in agricultural produce such is potato, the latter represents a highly consumed produce in Kosovo.
\end{abstract}

Keywords: Metals, plants, potato, environment, pesticides, herbicides.

(C) RASĀYAN. All rights reserved

\section{INTRODUCTION}

Kosovo is rich in many natural resources and it was obliged to create environmental policies and regulations through establishing special agencies to monitor the environmental health and increase of financing for the environment protection ${ }^{1,2}$. Due to heavy pollution in the last 15 years, Kosovo is forced to make progress in various areas such as in the improvement of the quality of air, water and soil ${ }^{3,4}$. However, in some areas, public policies are debatable such are the issues that pertain environment or natural resources due to great environment impact ${ }^{5,6}$. During the last 15 years, the public conscience has started to increase regarding the management of living environment ${ }^{7}$. There was the encouragement of policies to change the regulations that in turn started to deliver first fruits in solutions for environment problems $^{8,9}$. Our attention is concentrated in new generations for the solution of environment problems; this would be as a result of progress in scientific studies. The population is fed with agricultural produce without first knowing its quality ${ }^{10,11}$. The research should be focused on the emergence of health problems that have grave consequences for people.

\section{MATERIAL AND METHODS}

\section{EXPERIMENTAL}

The objective of monitoring of water quality of the water basins is to obtain sufficient information on the physical-chemical characteristics through the analysis of the heavy metal concentration in water in the obtained samples ${ }^{12,13}$.

Determination of chemical elements with the method (ICP-OES) ${ }^{22}$. (Coupled plasma with the induction mass spectroscopy), (Inducted Coupled Plasma - optical emission spectroscopy) in Lab in Ontario Canada. The concentration of heavy metals in potato is performed in the commercial lab. Agrovet in Fushe Kosove ${ }^{14-16}$. 
The tools that were used (Coupled plasma induction - spectroscopy of mass) and ICP-OES (Inducted Coupled Plasma - Optical Emission Spectroscopy) represents one of the most important methods of elementary analysis, due to the advantages that are in the limits of low detection for many elements, as well as high accuracy ${ }^{17,18}$.

Table-1: Standards of World Health Organization and of European Union for several chemical elements (mg/l) in potable water

\begin{tabular}{c|c|c}
\hline Cationic and anionic elements & WHO standards (1993) & EU Standards (1998) \\
\hline Lead & 0.01 & 0.01 \\
\hline Zinc & 0.3 & 1.0 \\
\hline Nickel & 0.02 & 0.02 \\
\hline Copper & 2.00 & 2.00 \\
\hline Cadmium & 0.02 & 0.005 \\
\hline
\end{tabular}

\section{RESULTS AND DISCUSSION}

The samples are taken in the water Basin of Iber River, one selected 6 sample locations, and in every place, one took two samples for analysis. Our aim is to perform research and comparison of the potato samples that are irrigated in the land plots near Iber River, compared with samples of potatoes that were cultivated with only atmospheric precipitation and those in greenhouses ${ }^{19,20}$.

1. The first sample of cultivated potato is that irrigated with water from Iber River which is contaminated due to mining activity in locations D1 and D4 ${ }^{21,22}$.

2. The second sample of cultivated potato is taken from the land plot which was $800 \mathrm{~m}$ far from Iber River and the potato is cultivated only with atmospheric precipitation, in locations D2 and D5 ${ }^{23}$.

3. The third sample of cultivated potato is taken from greenhouses in locations D3 and D6 and one utilized ecologically clean water for irrigation.

The final results of three groups with 12 subsamples are performed through comparison of concentration in three groups of cultivated potatoes in various climatic conditions.

In the first group, the potatoes those were cultivated with the water that was not previously chemically treated before being released to nature. The water is contaminated with heavy metals from mining activities of Trepca. The water is not chemically treated, but it is released as is in the Iber River, nowadays there are no fish in the river.

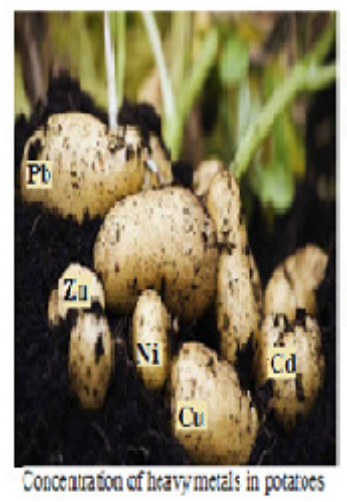

Potatoes irrigated by atmospheric precipitation

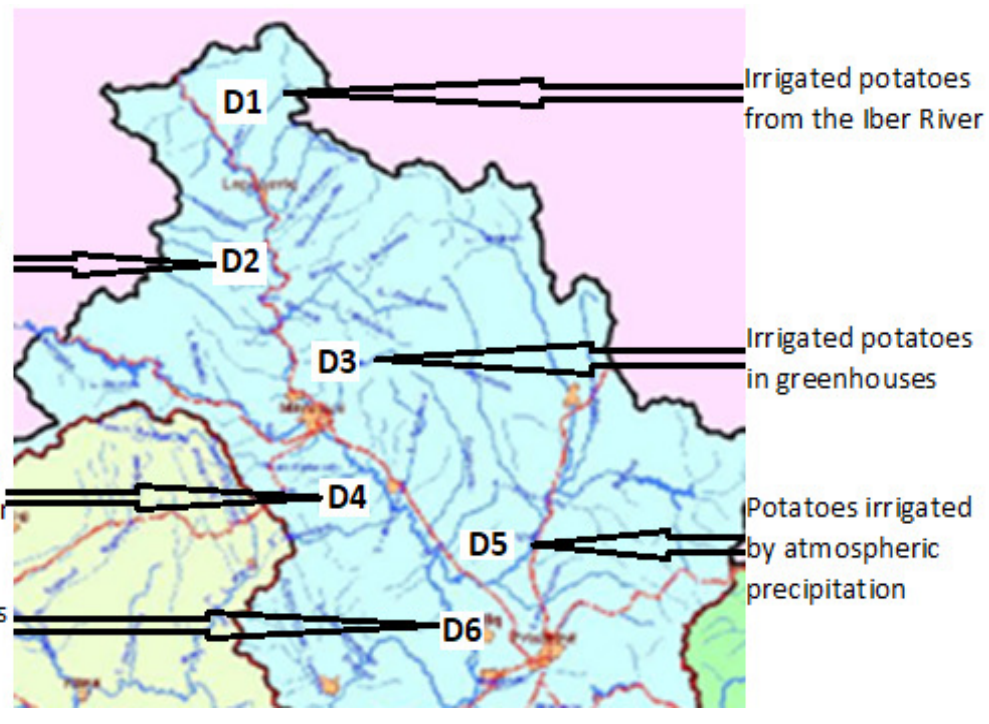

Fig.-1: The map of Iber river basin and the potato sample locations along Iber basin 
RASĀYAN J. Chem.

Vol. 11 | No. 2 |682-687 | April - June | 2018

The samples in D1 and subsamples (A1 and A2) locations, as well as D4 and subsample (A3 and A4) are analyzed and from the results, it emerges that the concentration of lead and other elements surpasses the international norms and it reaches up to $180 \mathrm{ppm}$ above the allowed limits for potable water Table-1.

In Fig.-2 the analysis of regression indicates that the results of four heavy elements are above the allowed norms.

Table-2: Tabular presentation of heavy metal in potatoes that were irrigated from Iber River (ppm)

\begin{tabular}{c|c|c|c|c}
\hline \multirow{2}{*}{ Metals } & \multicolumn{4}{|c}{ Sampling-points } \\
\cline { 2 - 5 } & \multicolumn{2}{|c}{ D1 ( two sub-samples) } & \multicolumn{2}{c}{ D4 (two sub-samples) } \\
\cline { 2 - 5 } & $\mathrm{A} 1$ & $\mathrm{~A} 2$ & $\mathrm{~A} 3$ & $\mathrm{~A} 4$ \\
\hline Lead $(\mathrm{Pb})$ & 1.56110 & 3.820875 & 2.528101 & 1.922240 \\
\hline Zinc $(\mathrm{Zn})$ & 22.6519 & 69.13335 & 12.72528 & 31.49166 \\
\hline Nickel $(\mathrm{Ni})$ & 2.47967 & 2.833286 & 45.27097 & 3.969009 \\
\hline Copper $(\mathrm{Cu})$ & 9.58601 & 19.11600 & 29.47450 & 14.76900 \\
\hline Cadmium $(\mathrm{Cd})$ & $<0,001$ & $<0,001$ & $<0,001$ & $<0,001$ \\
\hline
\end{tabular}

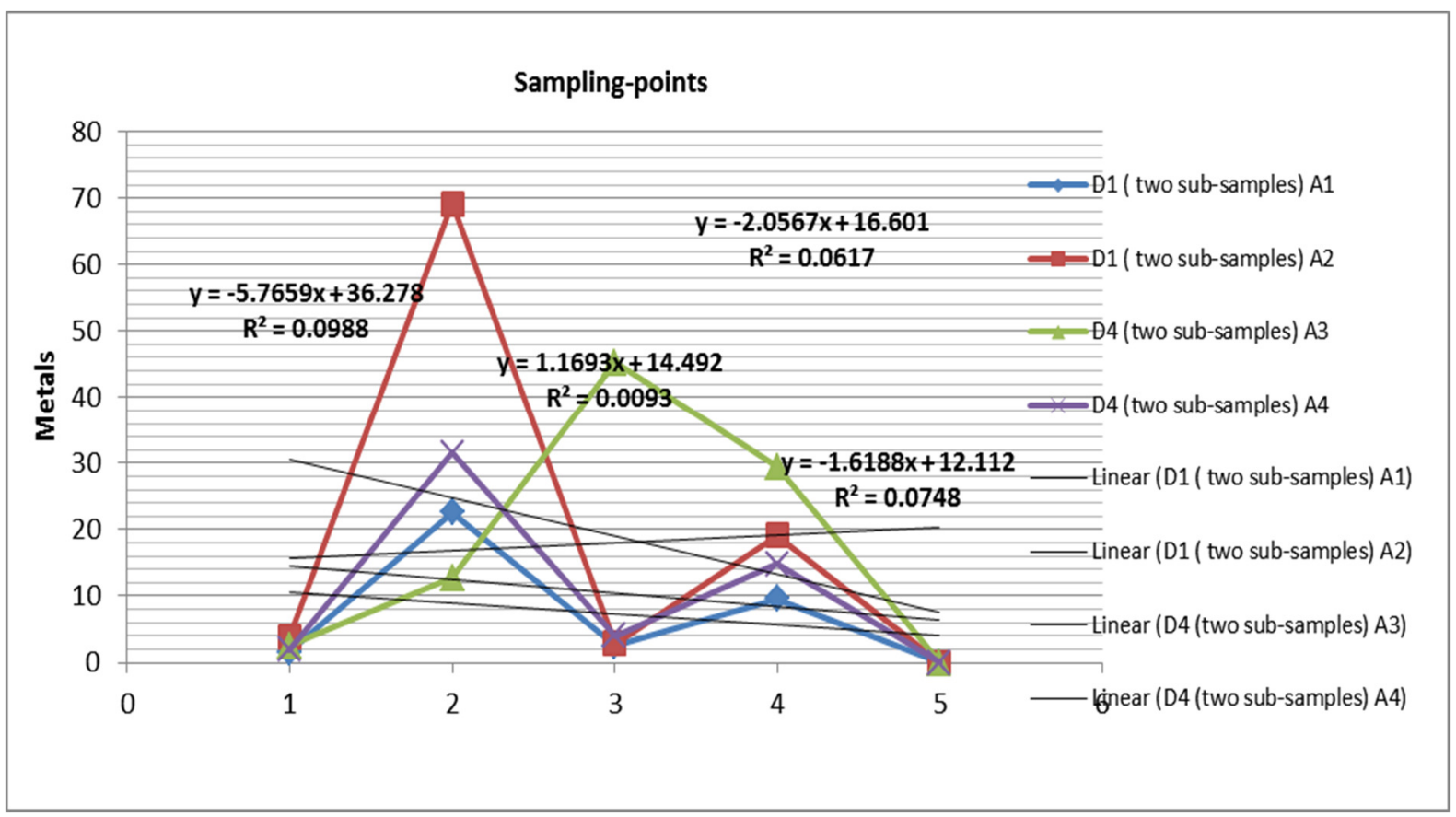

Fig.-2: Graphical presentation of the concentration of heavy metals D1, D4 and regress analysis

Table-3: Tabular presentation of heavy metal in potatoes that were irrigated only through atmospheric precipitation, D2 and D5 (ppm)

\begin{tabular}{c|c|c|c|c}
\hline \multirow{2}{*}{ Metals } & \multicolumn{4}{|c}{ Sampling-points } \\
\cline { 2 - 5 } & \multicolumn{2}{|c}{$\mathrm{D} 2$ ( two sub-samples) } & \multicolumn{2}{c}{ D5 ( two sub-samples) } \\
\cline { 2 - 5 } & $\mathrm{A} 1$ & $\mathrm{~A} 2$ & $\mathrm{~A} 3$ & $\mathrm{~A} 4$ \\
\hline Lead $(\mathrm{Pb})$ & 1.14240 & 2.920667 & 2.123450 & 1.122450 \\
\hline Zinc $(\mathrm{Zn})$ & 19.6347 & 56.13456 & 9.726780 & 28.49113 \\
\hline Nickel $(\mathrm{Ni})$ & 2.17923 & 2.133120 & 38.27023 & 3.119023 \\
\hline Copper $(\mathrm{Cu})$ & 7.91230 & 14.16510 & 22.48740 & 10.87600 \\
\hline Cadmium $(\mathrm{Cd})$ & $<0,001$ & $<0,001$ & $<0,001$ & $<0,001$ \\
\hline
\end{tabular}




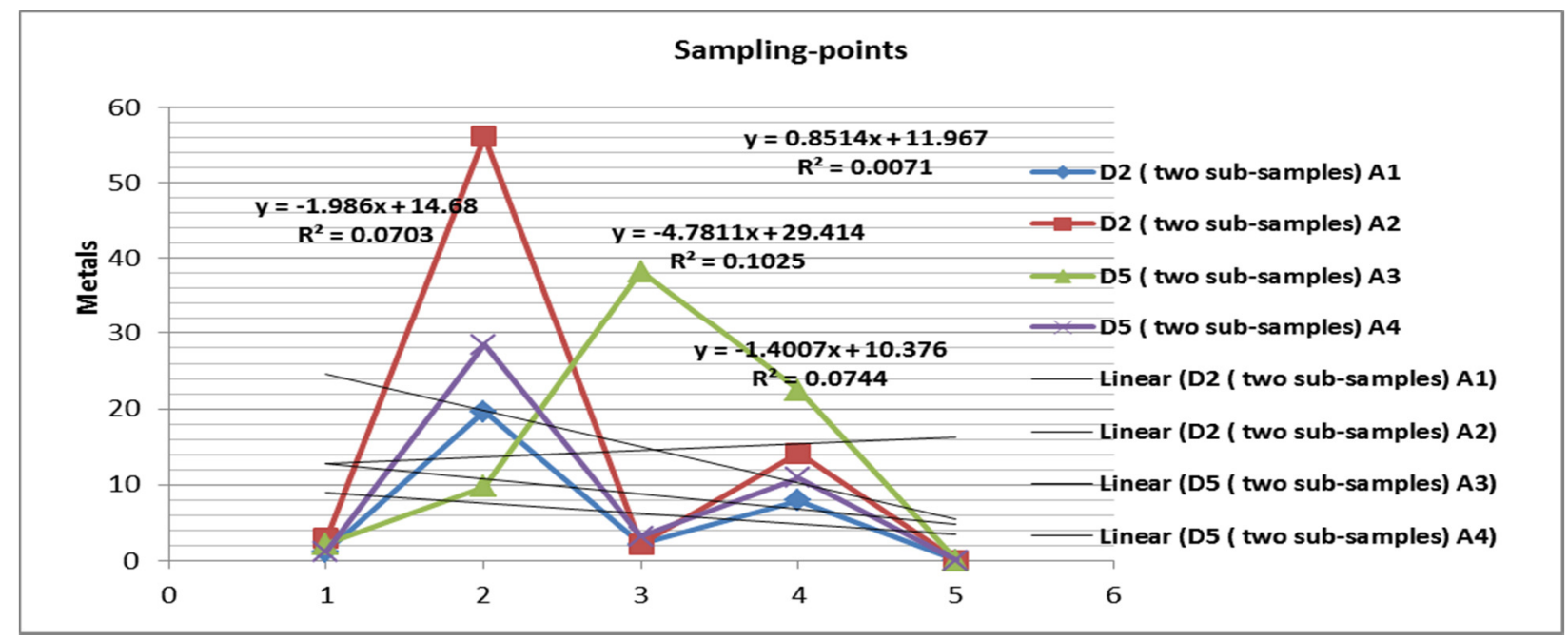

Fig.-3: Graphical presentation of the concentration of heavy metals in locations D2, D5 and regress analysis

In second group potatoes were cultivated without being irrigated from Iber River and they were irrigated only by the atmospheric precipitations. However, the air is polluted with heavy metals as a result of mining activities of Trepca. The sedimentation of heavy metals in agricultural land has an impact, too. The samples D2 with subsamples (A1 and A2) as well as D5 with subsamples (A3 and A4), based on the analyzed results the concentration of lead and other elements does not exceed the international norms, however they are increased up to maximum allowed level, compared to the standards for potable water, Table-1. In Fig.- 3 the analysis of regression indicates that the results of the heavy elements are in the maximum allowed norms.

Table-4: Tabular presentation of heavy metal in potatoes that were cultivated in greenhouses D3 and D6 (ppm)

\begin{tabular}{c|c|c|c|c}
\hline \multirow{2}{*}{ Metals $(\mathrm{ppm})$} & \multicolumn{4}{|c}{ Sampling-points } \\
\cline { 2 - 5 } & \multicolumn{2}{|c}{$\mathrm{D} 3$ ( two sub-samples) } & D6 ( two sub-samples) \\
\cline { 2 - 5 } & $\mathrm{A} 1$ & $\mathrm{~A} 2$ & 1.728720 & A34 \\
\hline Lead $(\mathrm{Pb})$ & 1.117800 & 1.920123 & 7.727890 & 12.49166 \\
\hline Zinc $(\mathrm{Zn})$ & 14.64512 & 35.13531 & 20.27097 & 1.569000 \\
\hline Nickel $(\mathrm{Ni})$ & 1.579670 & 1.633286 & 12.48762 & 9.798400 \\
\hline Copper $(\mathrm{Cu})$ & 5.997400 & 10.11600 & $<0,001$ & $<0,001$ \\
\hline Cadmium $(\mathrm{Cd})$ & $<0,001$ & $<0,001$ & & $<$ \\
\hline
\end{tabular}

In the third group, the potatoes that were cultivated without using the water from Iber River, without water from precipitation, they were isolated and only ecologically clean water was used. The contaminated air with heavy metals as a result of mining activities of Trepca could not penetrate and reach potatoes through the process of atmospheric precipitations and as a result, get deposited. Samples D3 and subsample (A1 and A2), as well as D6 with subsample (A3 and A4) from the analyzed results, it emerges that the concentration of lead and other heavy elements does not exceed the international norms. In Fig.-3 the analysis of regression indicates that the results of four heavy elements are within permitted levels.

\section{CONCLUSION}

In the present study, in the first group, the potatoes those were cultivated with the water that was not previously chemically treated before being released to nature. The water is contaminated with heavy metals from mining activities of Trepca. Water should be chemically treated. In second group potatoes were cultivated without being irrigated from Iber River and they were irrigated only by the atmospheric 
precipitations. However, the air is polluted with heavy metals as a result of mining activities of Trepca, based on the analyzed results the concentration of lead and other elements does not exceed the international norms, however, they are increased up to maximum allowed level, compared to the standards for potable water, Tab 1. In Fig 3 the analysis of regression indicates that the results of the heavy elements are in the maximum allowed norms.

In the third group, the potatoes that were cultivated without using the water from Iber River, without water from precipitation, they were isolated and only ecologically clean water was used. The contaminated air with heavy metals as a result of mining activities of Trepca could not penetrate and reach potatoes through the process of atmospheric precipitations and as a result, get deposited.

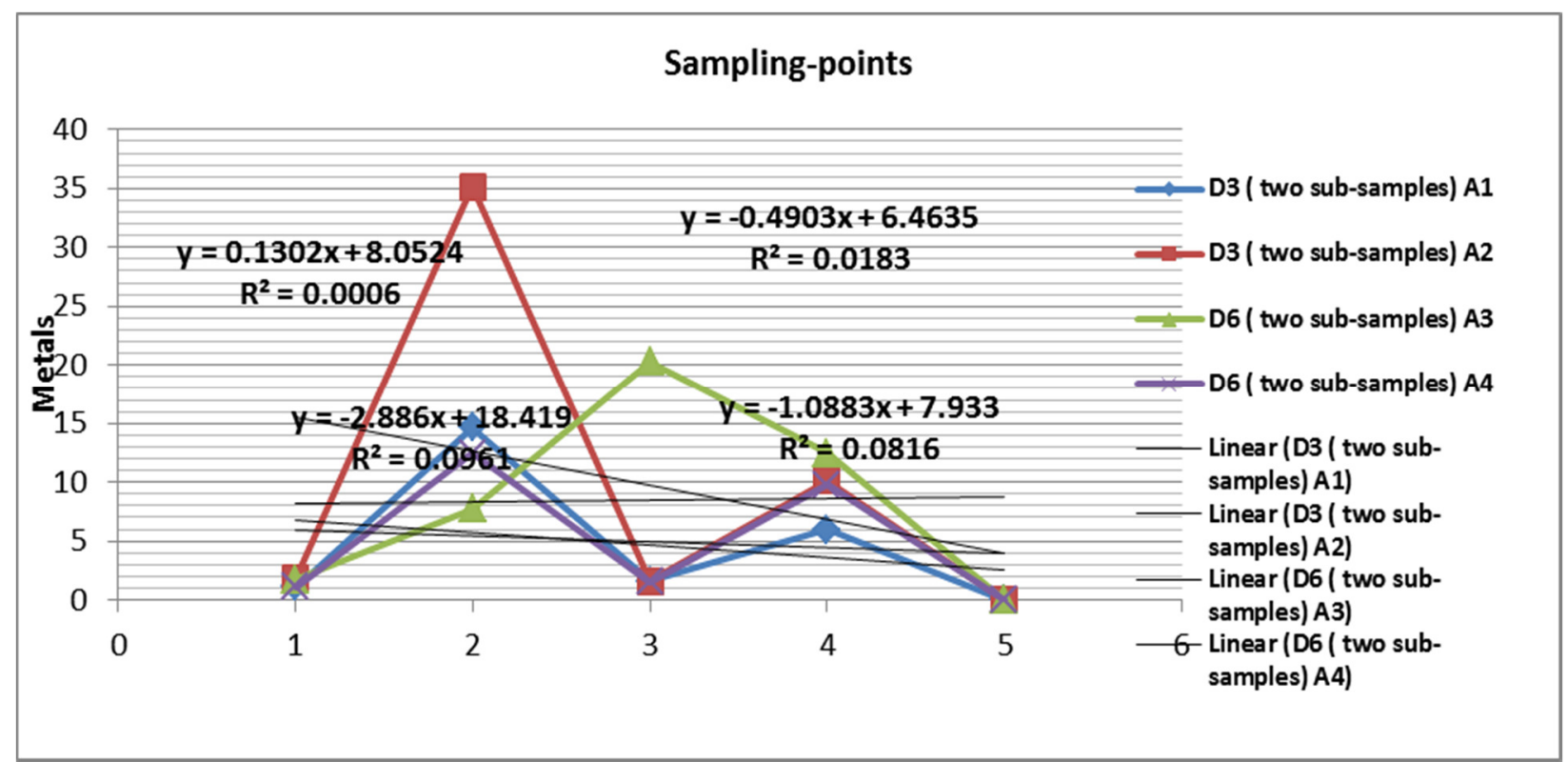

Fig.-4: Graphical presentation of the concentration of heavy metals in location D3, D6 and regress analysis

\section{REFERENCES}

1. J.R. Macknick, R. Newmark, G. Heath, and K.C. Hallet, Environmental Research Letters, 7(4), 2 (2012), DOI: 10.1088/1748-9326/7/4/045802

2. Y.A.B. Neolaka, E.B.S. Kalla, G. Supriyanto, Suyanto, N. N. T. Puspaningsih, Rasayan J. Chem., 10(2), 606 (2017), DOI: 10.7324/RJC.2017.1021710

3. S. Wang and Z.F. Zhu, Journal of Hazardous Materials B, 136(3), 946(2006), DOI: 10.1016/j.jhazmat.2006.01.038

4. R. Babilla-Ohlbaum, R. Ginocchio, P. H. Rodrìguez, A Cèspedes, S.Gonzàlez, H.E. Allen, G.E. Lagos, Environmental Toxicology and Chemistry, 20(12),2749 (2001), DOI:10.10002/etc.5620201214

5. T. Khairiah, M.K. Zalifah, Y.H. Yin, A. Aminah, Pakistan Journal of Biological Sciences, 7(8), 1441 (2004).

6. J.M. Swiader, G.W. Ware, Producing Vegetable Crops, 5th ed. Danville, IL: Interstate Publishers, Inc., pp: 658, (2002).

7. K. Pavelic', M. Hadžija, L. Bedrica, J. Pavelic', I. Dikic', M. Katic, M. Kralj, M.H. Bosnar, S. Kapitanovic', M. Poljak-Blaži, S. Križanac, R. Stojkovic', M. Jurin, B. Subotic' and M, C`olic, Journal of Molecular Medicine, 78(12), 712 (2001), DOI: 10.1007/s001090000176

8. Rahmi and Lelifajri, Rasayan J. Chem., 10(2), 634 (2017), DOI: 10.7324/RJC.2017.1021736 
9. M.A. Radwan, A.K. Salama, Food Chem Toxicol, 44(8), 1276 (2006) DOI:10.1016/j.fct.2006.02.004

10. B.K. Sharma, A. Adhvaryu, J.M. Perez, S.Z. Erhan, Journal of Agricultural and Food Chemistry, 53(17), 2961(2005), DOI: 10.1021/jf0486702

11. CODEX STAN 193-195: Codex General Standard for Contaminants and Toxins in Food and Feed. Adopted 1995. Revised 1997, 2006, 2008, 2009, Amended 2010. p. 1, 26, 27.

12. A. Bauer, Commun Soil Sci. Plant Anal., 2(3), 161 (1971).

13. F.A. Nicholson, S.R. Smith, B.J. Alloway, C. Carlton-Smith, B.J. Chambers, Sci. Total Environ., 311 (1-3), 217 (2003), DOI:10.1016/S0048-9697(03)00139-6

14. K. Chojnacka, A. Chojnacki, H. Gorecka and H. Gorecki, Science of the Total Environment, 337(13), 175 (2005), DOI:10.1016/j.scitotenv.2004.06.009

15. G.M. Geraldson, G.R. Klacan, O.A. Lorenz, Plant analysis as an aid in fertilizing vegetable crops. In: L.M. Walsh, J.D. Beaton, eds. Soil Testing and Plant Analysis. Madison, WI: Soil Science Society of America, pp: 367 (1973).

16. L. Järup, British Medical Bulletin, 68(1), 167(2003), DOI: 10.1093/bmb/ldg032

17. S. Sinthusamran, S. Benjakul, H. Kishimura, Food Chem., 152, 276 (2014), DOI: 10.1016/j.foodchem.2013.11.109

18. W. Trisunaryanti, T. Triyono, D. Fibirna, Indonesian Journal of Chemistry, 3(2), 80(2003), DOI: 10.22146/ijc. 21890

19. R.K. Sharma, M. Agrawal, F.M. Marshall, Environ. Poll., 154(2),255 (2008) DOI:10.1016/j.envpol.2007.10.010

20. D.G. Lurie, J.M. Holden, A. Schubert, W.R.Wolf, N.J. Miller-Ihli, Journal of Food Composition \& Analysis, 2(4), 307 (1989), DOI: 10.1016/0889-1575(89)90002-1

21. J. Usero, E. Gonza-Regalado, I. Gracia, Environ. Int., 23(3), 291(1997).

22. K. Steenland, P. Boffetta, American Journal of Industrial Medicine, 38(3), 295, (2000), DOI:10.1002/1097-0274(200009)38:3<295::AID-AJIM8>3.0.CO;2-L

23. P.G. Reeves, R.L. Chaney, Sci. Total Environ., 13(1), 398(2008)

[RJC-3024/2018] 